\title{
Influence of pore water pressure to seepage and stability of embankment dam (case study of Sermo Dam Yogyakarta, Indonesia)
}

\author{
Undayani Cita Sari ${ }^{1 *}$, Sri Prabandiyani Retno Wardani ${ }^{1}$, Suharyanto ${ }^{1}$, and Windu Partono ${ }^{1}$ \\ ${ }^{1}$ Civil Engineering Department, Faculty of Engineering, Diponegoro University, 50275 Semarang, Indonesia
}

\begin{abstract}
Today, water requirements are not analogously with its availability. Therefore, build water reservoir dam is one of the simple concepts for fulfilling water requirements. Embankment dam is one of the most popular dam build in Indonesia. Stability of embankment dam should be taken into account to evaluate the safety condition in retaining water. Safety against seepage is one of the most important steps for checking the possibility of failure of embankment dam. PLAXIS is alternative software that can be used for evaluating safety of embankment dam due to seepage condition. This paper explains the study of pore water pressure and seepage effects against Sermo Dam safety using PLAXIS and compares it with field measurement data from piezometer and V-Notch monitoring. The study was conducted during dam operational conditions. The analysis was carried out using Mohr-Coulomb model to calculate discharge of seepage and settlement. The value of pore water pressures within the model, upstream and downstream, positions are then reviewed with the real dam. The results of model analysis shows that the more higher water level within the dam reservoir the more higher pore water pressure will be happened that affects in increasing discharge of seepage and settlement of dam.
\end{abstract}

\section{Introduction}

Construction of the dam is needed so that water as a fundamental natural resource, can be long in the land before flowing back into the sea, as well as allow time to absorption the ground water. In order for the benefits to be sustainable, it needs to know the safety, especially when the dam operates. More than $70 \%$ dam in Indonesia is an embankment dam as stated by Soedibyo [1]. In this type of embankment dam, it should be taken into account in order to ensure its stability in retaining water.

One of the principal criteria for dam safety is safe against failure due to seepage [2]. Seepage through dam body and foundation can cause erosion. The transport of material through dam by seepage flow may result in fractures, which can reduce the capacity of dam. In addition, excessive seepage can cause reed erosion increasingly and potentially cause landslide until the dam collapse. Sudardja [3] stated that the seepage that occured within embankment dam is affected by water level height.

In addition, with the change in water level can also affect the increase in pore water pressure. Pore water pressure can trigger embankment slope instability and deformation. Morton et al. [4] study on the high walls suggested that the increase in pore water pressure will lead to a reduction in stress, while decreasing pore water pressure will lead for an increasing in stress. When the stress on land increases, it can increase strength of the ground to against instability resulting landslide on the slope. On the other way, if the stress on the ground is reduced, the more easily on slopes in landslide.

Deformation due to increased water levels studied on the Shuibuya Dam, China which is rockfill dam with impermeable layer of concrete in the upstream (Concrete Faced Rockfill Dam) [5]. Observation instrument for monitoring done at WS01 to WS11 which measures the deformation in the dam. Observations monitoring shows that when the water level increases, the settlement in dam also increases. In addition, the observation was also made by using Interferometric Synthetic Aperture Radar (InSAR), which has result that consistent with the result from the monitoring measurements. The combination of the results between monitoring in-situ and InSAR measurements indicate that the settlement is affected by gravity and the water level of reservoir at the dam, so that the largest settlement occurred at the peak of the dam.

The influence of dam water level with settlement is also given using a laboratory model of the embankment dam [6]. The study was conducted at three variations of the upstream slope of the dam, 1:1;1:1.5; and 1:2. The result shows, when water level height increases, then the deformation is getting bigger. In addition, with the fill on the upstream slope steeper makes sliding on the downstream slope of the dam models more quickly occur. 
Based on these problems, it is necessary to study the seepage and stability analysis (in this case to be reviewed is settlement), to analyze the security of the dam caused by the influence of pore water pressure. Seepage and stability analyzes performed on operational condition so that it can be seen the influence of pore water pressure in these conditions. This study took place in the Sermo Dam located in the Hargowilis village, Kokap, Kulon Progo, Yogyakarta, Indonesia.

\section{Research method}

The research method is an important thing which is used as reference studies for research stage. In this study, the first stage is carried out based on the field data collection of water level from monitoring Peil Schaal and discharge of seepage monitoring $\mathrm{V}$-Notch in the field at zero rainfall.

Sermo Dam modeling done by using PLAXIS in analyzing every operational conditions reviewed in the study. There are three cross sections on Sermo Dam, which are sta 12 , sta 15 , and sta 18 , but in this study the cross section is reviewed in sta 15 . Further analysis discharge of seepage, settlement, and the pore water pressure are based on modeling using PLAXIS and the explanation can be seen as follows.

\subsection{Field data collection}

Water levels are needed to determine the conditions used in this research analysis. In this study, determined the water level used is at the zero rainfall. Then graphed the relation between water level and discharge of seepage measurement with V-Notch, so it can be determined the discharge of seepage for each condition water levels is analyzed. Graph relation between water level and discharge of seepage can be seen in Figure 1, which uses 120 data field from 2000 to 2014 based on Departemen Pekerjaan Umum [7]. The graph's correlation value $\left(\mathrm{R}^{2}\right)$ is 0.666 .

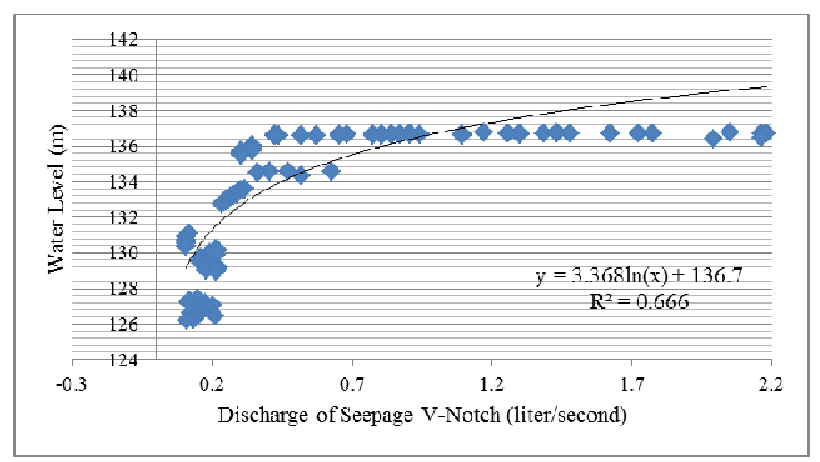

Fig. 1. Correlation between water level and discharge of seepage without rainfall condition

Water levels reviewed in this study analysis are 126.33 meters; 133.47 meters; 136.60 meters; and 136.71 meters. The selection of water level was adjusted to the availability of data piezometers in the field which is recorded every seven days. This is because before analysing this research study, then also do the data validation checks between the value of pore water pressure monitoring with piezometers in the field and value of pore water pressure modeling simulation results using PLAXIS.

Based on the graph in Figure 1 and four water level that have been determined for analysing in this study, it can be obtained the new discharge of seepage V-Notch that can be seen in Table 1. Standard error of 120 data is 0.05 , whereas the standard deviation is 0.537 , so that can be determined the uper value limit and lower value limit of the new discharge of seepage. The uper value limit and lower value limit for the new disharge of seepage can be seen in Table 1 .

Table 1. New discharge of seepage data through V-Notch

\begin{tabular}{|c|c|c|c|}
\hline $\begin{array}{c}\text { Water } \\
\text { Level } \\
\text { (m) }\end{array}$ & $\begin{array}{c}\text { Discharge of } \\
\text { Seepage V-Notch } \\
\text { (liter/sec) }\end{array}$ & $\begin{array}{c}\text { Uper Limit } \\
\text { (liter/sec) }\end{array}$ & $\begin{array}{c}\text { Lower } \\
\text { Limit } \\
\text { (liter/sec) }\end{array}$ \\
\hline 126.33 & 0.05 & 0.58 & 0.00 \\
\hline 133.47 & 0.38 & 0.92 & 0.00 \\
\hline 136.60 & 0.97 & 1.50 & 0.43 \\
\hline 136.71 & 1.00 & 1.54 & 0.46 \\
\hline
\end{tabular}

\subsection{Modeling of Sermo Dam}

Sermo Dam is included in zonal dam, consisting of permeable zone (shell), impermeable zone (core), and a filter zone (classification zone based on Sosrodarsono and Takeda [8]). Sermo Dam itself is a rockfill dam zonal types with clay core.

Figure 2 shows a cross-sectional Sermo Dam which is reviewed in this study, namely the sta 15 . Figure 3 shows a cross section Sermo Dam on the sta 15 which is modeled using PLAXIS. It should be noted that at this Sermo Dam given chamber of 2.142 meters, from a height of 141.00 meters to 143.142 meters.

This study is conducted using modeling MohrCoulomb on PLAXIS, which is applying the finite element method by dividing the dam structure into small dots related with nodal (meshing). The finer meshing is done, then the result will be more accurate. In this study, using very fine type of meshing with 15 -node. Very fine type of meshing produces about 1000 elements [9].

Parameters of material at the dam determined based on data from soil investigation by Caturbina Guna Persada [10] and field testing data from Departemen Pekerjaan Umum [11]. The data's parameters materials bedrock based on design data from Departemen Pekerjaan Umum [12].

Determining the value of permeability coefficient is from the result discharge of seepage measurements using PLAXIS modeling and calibrated with discharge of seepage from monitoring V-Notch in the field at water level 135.20 meters. The result in this discharge of seepage monitoring with V-Notch is 1.055 liters/second [7]. 


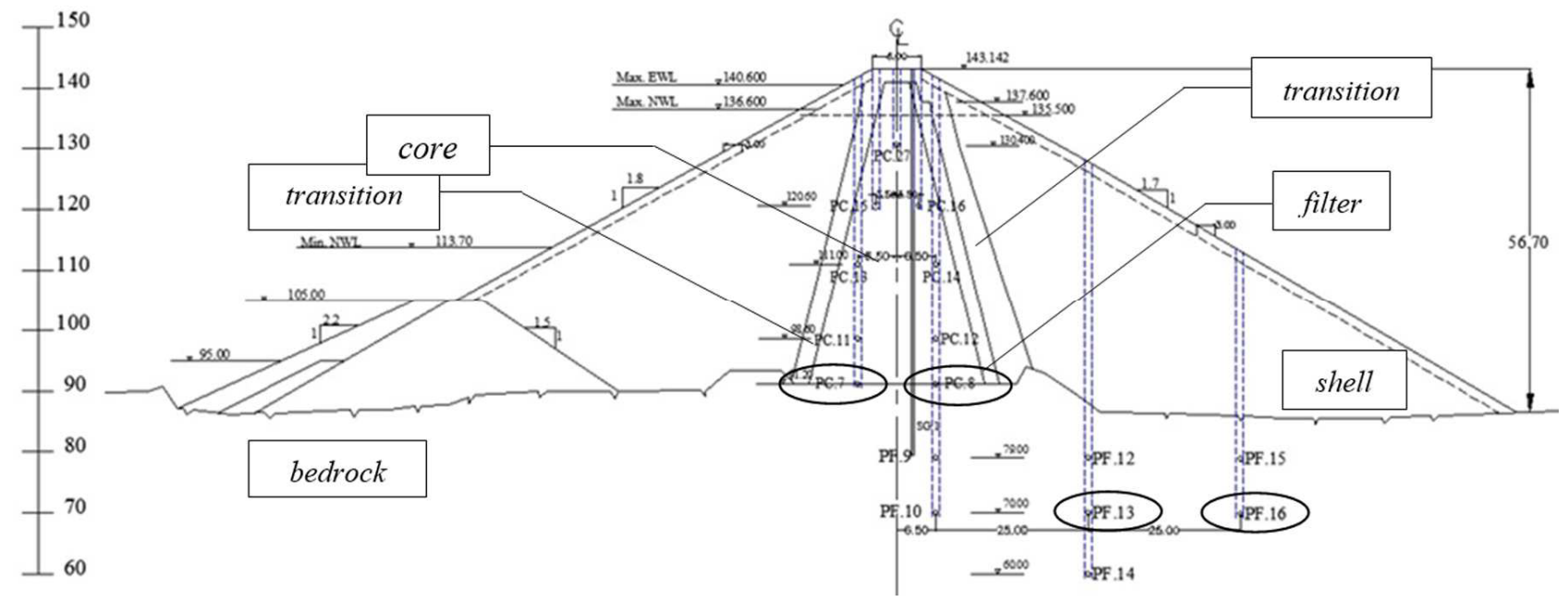

Fig. 2. Location of piezometer within the cross section of Sermo Dam [13]

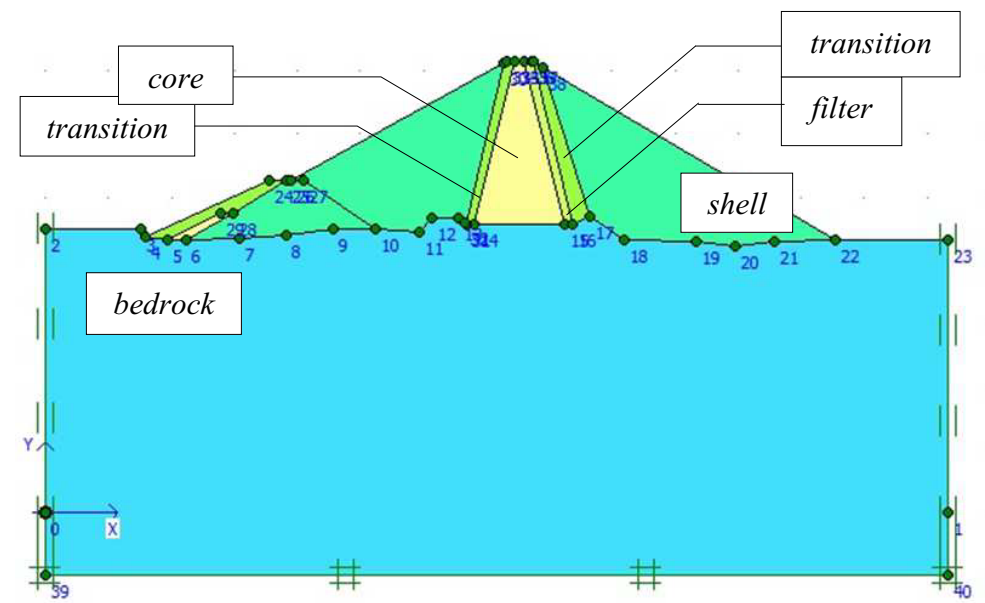

Fig. 3. PLAXIS modeling overview of Sermo Dam

Table 2. PLAXIS parameters of material used in the model of Sermo Dam

\begin{tabular}{|c|c|c|c|c|}
\hline \multirow[b]{2}{*}{$\begin{array}{c}\text { Zone of } \\
\text { Dam }\end{array}$} & \multicolumn{4}{|c|}{ Parameter } \\
\hline & $\begin{array}{l}\gamma_{\text {saturated }} \\
\left(\mathbf{k N} / \mathrm{m}^{3}\right)\end{array}$ & $\begin{array}{c}\gamma_{\text {unsaturated }} \\
\left(\mathbf{k N} / \mathbf{m}^{3}\right)\end{array}$ & $\begin{array}{c}\text { Cohesion } \\
(c) \\
\left(\mathbf{k N} / \mathbf{m}^{2}\right)\end{array}$ & $\begin{array}{c}\text { Angle of } \\
\text { Friction } \\
\left({ }^{0}\right)\end{array}$ \\
\hline Core & 18.74 & 15.41 & 8.3 & 32 \\
\hline Filter & 21 & 18.5 & 0.001 & 35 \\
\hline Transition & 21.7 & 21.6 & 0.001 & 35 \\
\hline Shell & 21 & 20 & 0.001 & 43 \\
\hline Bedrock & 21.82 & 20.12 & 680 & 55 \\
\hline
\end{tabular}

Table 3. PLAXIS parameters of material used in the model of Sermo Dam

\begin{tabular}{|l|c|c|c|}
\hline \multirow{2}{*}{$\begin{array}{c}\text { Zone of } \\
\text { Dam }\end{array}$} & \multicolumn{3}{|c|}{ Parameter } \\
\cline { 2 - 4 } & $\begin{array}{c}\text { Coefficient of } \\
\text { Permeability } \\
(\boldsymbol{k}) \mathbf{( m / d a y )}\end{array}$ & $\begin{array}{c}\text { Young's } \\
\text { Modulus (E) } \\
\left(\mathbf{k N} / \mathbf{m}^{\mathbf{2}}\right)\end{array}$ & $\begin{array}{c}\text { Poisson } \\
(\boldsymbol{v})\end{array}$ \\
\hline Core & $2.32 \times 10^{-4}$ & 5500 & 0.45 \\
\hline Filter & 134.10 & 6000 & 0.30 \\
\hline Transition & 14.292 & 8000 & 0.30 \\
\hline Shell & 12154.69 & 200000 & 0.35 \\
\hline Bedrock & 6.00 & 210000 & 0.45 \\
\hline
\end{tabular}

Calibration the parameters material is performed at three station locations within Sermo Dam, which are sta 12 , sta 15 , and sta 18 , along 190 meters as the length of the peak of dam, so expect the results is obtained in accordance with the real situation on the field. Neither, the parameter values of Young's modulus and Poisson value figures on core zone, which are determined using back analysis method by calibration with settlement gauge. Thus parameter of materials values shown in Table 2.

\subsection{Discharge of seepage analysis}

Discharge of seepage calculation by analyzing the resultant discharge of the dam cross-section modeling using PLAXIS, which is calculated from the total discharge of seepage along 190 meters as the length of the dam. Discharge of seepage calculation results using modeling PLAXIS can be compared with measurements of the new discharge of seepage from V-Notch which has been calculated in Table 1 , for each condition is analyzed.

Pore water pressure is measured at each stress point in PLAXIS modeling that has nearly same coordinates with the coordinates of the piezometer in field under review. Piezometer's reviewed in this study (see Figure 
2) are on the upstream side of the $\mathrm{PC}-7$ and $\mathrm{PC}-8$ (core zone). Meanwhile, the downstream are in $\mathrm{PF}-13$ and $\mathrm{PF}-$ 16 (bedrock zone). Coordinates $\mathrm{PC}-7$ and $\mathrm{PC}-8$ are located at $143.85 ; 91.20$ and $156.85 ; 91.20$. While coordinate PF-13 and PF-16 are located at $181.85 ; 70.0$ and $206.850 ; 70.0$. In this study do a review of the settlement, as one aspect of stability. Analyse settlement is to look at the maximum settlement that occurred in the Sermo Dam using PLAXIS modeling.

\section{Results and discussions}

Based on the analysis performed, the results discharge of seepage using PLAXIS modeling in each waters levels are analyzed in this study shown in Table 3. From Table 3 it can be concluded that the higher water level then also higher the discharge of seepage. This is according to research that have been done before [3], which examined the effects of fluctuations in water level in the dam seepage using laboratory models. The stability in this study to evaluated is settlement. Large drop settlement can lead to instability of the dam. The relation of water level and the maximum settlement in the core zone is shown in Table 4.

Table 4. Discharge of seepage analysis on Sermo Dam using PLAXIS

\begin{tabular}{|c|c|c|c|c|}
\hline $\begin{array}{c}\text { Water } \\
\text { Level } \\
\text { (m) }\end{array}$ & $\begin{array}{c}\text { Discharg } \\
\text { e of } \\
\text { Seepage } \\
\text { V-Notch } \\
\text { (It/sec) }\end{array}$ & $\begin{array}{c}\text { Uper } \\
\text { Limit } \\
\text { (It/sec) }\end{array}$ & $\begin{array}{c}\text { Lower } \\
\text { Limit } \\
\text { (It/sec) }\end{array}$ & $\begin{array}{c}\text { Discharge } \\
\text { of Seepage } \\
\text { Using } \\
\text { PLAXIS } \\
\text { (It/sec) }\end{array}$ \\
\hline 126.33 & 0.05 & 0.58 & 0.00 & 0.58 \\
\hline 133.47 & 0.38 & 0.92 & 0.00 & 0.69 \\
\hline 136.60 & 0.97 & 1.50 & 0.43 & 0.71 \\
\hline 136.71 & 1.00 & 1.54 & 0.46 & 0.83 \\
\hline
\end{tabular}

* Based on Figure 1 and Table 1

Table 5. Maximum settlement on core zone of Sermo Dam using PLAXIS modeling

\begin{tabular}{|c|c|c|}
\hline No & $\begin{array}{c}\text { Water Level } \\
(\mathbf{m})\end{array}$ & $\begin{array}{c}\text { Maximum Settlement in the } \\
\text { Core Zone (m) }\end{array}$ \\
\hline 1 & 126.33 & 1.10 \\
\hline 2 & 133.47 & 1.14 \\
\hline 3 & 136.60 & 1.16 \\
\hline 4 & 136.71 & 1.16 \\
\hline
\end{tabular}

Table 4 shows that in operational condition, the higher water level so does the settlement. This is relevant with research that have been done before [5], which examines monitoring settlement in Shuibuya Dam, China. The monitoring results show that when the water level increases, the settlement in dam will also increase. Additionally, there is also a study that studied the effect of fluctuations in water level in the dam deformation in laboratory model which is giving relevant conclusion [6].
According to the tolerable resulting discharge of seepage should not exceed 0.56 liters/minute/meter, for high dams greater than 40 meters [14]. The sta 15 of Sermo Dam which is analyzed in this study, has a height of 56.70 meters (Figure 2). Meanwhile, based on Table 3 , the maximum discharge using PLAXIS is in the water level 136.71 meters with a discharge of 0.83 liters/sec or equal to 0.26 liters $/$ minute/meter. The discharge value is smaller than 0.56 liters/minute/meter, so it is still less than the tolerable discharge requirements. Meanwhile, when seen from the settlement, the value of the maximum settlement result from numerical modeling using PLAXIS is 1.16 meters in water level of 136.71 meters (Table 4). The tolerance settlement at the end construction is $2 \%$ of dam height [15]. It is approaching with the value of settlement result from modeling using PLAXIS.

In this study, also given the relation between the water level and pore water pressure result using PLAXIS modeling. As already explained, that piezometers are reviewed on the upstream and downstream, they are PC7, PC-8, PF-13, and PF-16 (Figure 2). The value of pore water pressure from PLAXIS modeling is obtainabled by taking the stress point in PLAXIS which have similiar or approaching coordinates (in $\mathrm{x}$-axis and $\mathrm{y}$-axis) with the coordinates in each piezometer that is reviewed. Relation between water level and pore water pressure in PC-7 and PC-8 modeling using PLAXIS can be seen in Table 5 . Meanwhile Table 6 shown the relation between the water level and pore water pressure in PF-13 and PF-16.

Table 6. Relation between water level and pore water pressure on the PC-7 and PC-8 using PLAXIS

\begin{tabular}{|c|c|c|c|c|}
\hline \multirow{2}{*}{$\begin{array}{c}\text { Water } \\
\text { Level } \\
(\mathbf{m})\end{array}$} & \multicolumn{4}{|c|}{ Pore Water Pressure } \\
\cline { 2 - 5 } & \multicolumn{2}{|c|}{$(\mathbf{P C}-7)$} & \multicolumn{2}{c|}{ (PC-8) } \\
\hline 126.33 & $34.57 \mathrm{kPa}$ & $126.32 \mathrm{~m}$ & $16.83 \mathrm{kPa}$ & $126.67 \mathrm{~m}$ \\
\hline 133.47 & $41.20 \mathrm{kPa}$ & $133.46 \mathrm{~m}$ & $33.32 \mathrm{kPa}$ & $130.97 \mathrm{~m}$ \\
\hline 136.60 & $54.30 \mathrm{kPa}$ & $135.59 \mathrm{~m}$ & $45.88 \mathrm{kPa}$ & $132.25 \mathrm{~m}$ \\
\hline 136.71 & $66.19 \mathrm{kPa}$ & $136.50 \mathrm{~m}$ & $61.13 \mathrm{kPa}$ & $135.25 \mathrm{~m}$ \\
\hline
\end{tabular}

Table 7. Relation between water level and pore water pressure on the PF-13 and PF-16 using PLAXIS

\begin{tabular}{|c|c|c|c|c|}
\hline \multirow{2}{*}{$\begin{array}{c}\text { Water } \\
\text { Level } \\
(\mathbf{m})\end{array}$} & \multicolumn{3}{|c|}{ Pore Water Pressure } \\
\cline { 2 - 5 } & \multicolumn{2}{|c|}{$\mathbf{( P F - 1 3 )}$} & \multicolumn{2}{c|}{ (PF-16) } \\
\hline 126.33 & $6.79 \mathrm{kPa}$ & $88.46 \mathrm{~m}$ & $4.30 \mathrm{kPa}$ & $86.67 \mathrm{~m}$ \\
\hline 133.47 & $9.50 \mathrm{kPa}$ & $87.66 \mathrm{~m}$ & $9.47 \mathrm{kPa}$ & $85.59 \mathrm{~m}$ \\
\hline 136.60 & $14.26 \mathrm{kPa}$ & $87.01 \mathrm{~m}$ & $10.54 \mathrm{kPa}$ & $85.28 \mathrm{~m}$ \\
\hline 136.71 & $16.17 \mathrm{kPa}$ & $86.97 \mathrm{~m}$ & $11.54 \mathrm{kPa}$ & $85.37 \mathrm{~m}$ \\
\hline
\end{tabular}

Table 5 and Table 6 show that the higher water level, the higher the pore water pressure, and at a position downstream of the dam (bedrock zone in PF-13 and PF16), the pore water pressure will be smaller than in upstream of the dam (core zone in PC-7 and PC-8). In addition, it can be concluded that when the water level increases, the pore water pressure will also increases. Increasing water level can cause an increase pore water 
pressure, this is because the material is in the saturated condition resulting from the flow of water seepage into the body of the dam, as a consequence of the water level height. Saturated material will increase pore water pressure, especially with the long drainage because the material in the core of Sermo Dam is a cohesive soil (as a location of PC-7 and PC-8). So that, in $\mathrm{PC}-7$ and $\mathrm{PC}-8$ have value of pore water pressure greater than in the PF-13 and PF-16. From Figure 2, is known that PF-13 and PF-16 are located in the bedrock zone or foundation of the dam, which is composed of andesite breccia rocks making the material easier for draining water seepage.

The increase in pore water pressure that occurs may lead to increases the discharge of seepage, which can be seen in Table 3. The discharge of seepage could cause settlement that occurred also increased significantly (Table 4). Increasing the settlement occured because of water seepage in the dam body causes the material changes in saturated condition. Then, the value of the materials will changed. So that, the stress will reduced. The stress reduction will impact on increasing the settlement and reducting the stability of dam in retaining water. This is also according to research conducted on a high wall [4], which is an increasing pore water pressure will lead to a reduction in stress, while decreasing pore water pressure will lead to an increasing in stress. When the stress increases, so that can increase the soil strength to against instability.

\section{Conclusion}

Based on the existing problem in this study is about the influence of pore water pressure on the seepage and stability with a case study on Sermo Dam, could be concluded as follows:

1. Analysis of the PLAXIS modeling shows that water levels affect the increase of pore water pressure. The higher the water level, the higher the pore water pressure. With the increase in pore water pressure, the discharge of seepage that occurs will also increase.

2. Increasing the pore water pressure due to change of water level height led to increased discharge of seepage and settlement. This is due to water seepage causes the materials become saturated and the value of materials will changed and the stress will reduced. Reduction of stress will impact on the instability of dam structure.

This research supported by Work Unit of The Central River Region (BBWS) Serayu Opak for helping to collect data Sermo Dam.

\section{References}

1. Indonesian National Committee on Large Dams. (Buletin No.38-39-40 TH.XII Kwartal I/II/III 2009, 16, 2010)

2. Departemen Pekerjaan Umum. Pedoman Pengendalian Rembesan pada Bendungan Urugan. (Jakarta: Direktorat Jenderal Sumber Daya Air, Direktorat Sungai dan Waduk, 2005)

3. H. Sudardja, Civil Engineering Forum, XXI/1, 1199 - 1207 (2012)

4. K.L. Morton, M.C. Muresan, F.R. Debswana, Importance of Pore Pressure Monitoring in High Walls. The Southern African Institute of Mining and Metallurgy, 225 - 238 (2008)

5. W. Zhou, S. Li, Z. Zhou, X. Chang, Remote Sensing of Deformation of a High Concrete-Faced Rockfill Dam Using InSAR: A Study of the Shuibuya Dam, China. Remote Sens 8, 255, 1 - 15, (2016)

6. N. Meisyara. Pengaruh Fluktuasi Muka Air Reservoir terhadap Deformasi dan Stabilitas Bendungan Tanah (Uji Model Laboratorium). (Tesis Universitas Gadjah Mada, 2012)

7. Departemen Pekerjaan Umum. Bendungan Sermo. (Satuan Kerja Balai Besar Wilayah Sungai Serayu Opak, Yogyakarta, 2015)

8. S. Sosrodarsono and K. Takeda. Bendungan Type Urugan. (Jakarta: Pradnya Paramita, 1977)

9. R.B.J. Brinkgreve. Manual PLAXIS 2D Version 8. (Delft University of Technology \& PLAXIS b.v, Belanda, 2007)

10. Caturbina Guna Persada. Pekerjaan Studi Faktor Lingkungan dan Stabilitas Lereng Bendungan Sermo Tahun 2005. (Laporan Studi Teknik, Yogyakarta, 2005)

11. Departemen Pekerjaan Umum. Laporan Kajian Pelaksanaan Pembangunan Waduk Sermo D.I. Yogyakarta (Direktorat Jenderal Pengairan, Unit Keamanan Bendungan, Yogyakarta, 1996)

12. Departemen Pekerjaan Umum. Pekerjaan Desain Detail Proyek Bendungan Sermo. (Direktorat Jenderal Pengairan, Direktorat Irigasi II, Proyek Irigasi Kali Progo, Yogyakjarta, 1985)

13. Departemen Pekerjaan Umum. Laporan Ringkas Waduk Sermo. (Direktorat Jenderal Pengairan, Proyek Pembangunan Waduk Sermo, 1994)

14. B. G. Look. Handbook of Geotechnical Investigation and Design Tables. (Taylor \& Francis Group, London, 2007)

15. C. Kutzner. Earth and Rockfill Dams, Principles of Design and Construction. (A.A. Balkema, Rotterdam, Brookfield, 1997) 